\title{
HUBUNGAN RASA KEBERSYUKURAN DENGAN ADVERSITY QUOTIENT PADA MAHASISWA PENERIMA BEASISWA BIDIKMISI UIN IMAM BONJOL
}

\author{
Sapni Alpionika \\ Universitas Islam Negeri (UIN) Imam Bonjol Padang, sapnialpionika0204@gmail.com \\ Murisal \\ Universitas Islam Negeri (UIN) Imam Bonjol Padang, murisaldesember1972@gmail.com \\ Widia Sri Ardia \\ Universitas Islam Negeri (UIN) Imam Bonjol Padang, widiasri@uinib.ac.id
}

Diterima: 30 Januari 2019 Direvisi: 2 Mei $2019 \quad$ Diterbitkan: 30 Juni 2019

\begin{abstract}
This research aimed to find out the level of gratification, the level of adversity quotient, and the relationship of gratitude with adversity quotient in UIN Imam Bonjol Padang bidikmisi recipient students. This research uses quantitative methods with data analysis techniques, namely Pearson correlation analysis, which the SPSS program version 20.0 for windows. The independent variable in this study is a gratification, and the dependent variable is the adversity quotient. Research subjects numbered 229 students receiving the bidikmisi UIN Imam Bonjol Padang. Data collection techniques used in this study are psychological scales, namely the scale of gratitude that the authors arrange themselves with a validity of 48 out of 60 items and have a reliability of 0,934 and an adversity quotient scale that the authors compose themselves with a validity of 50 out of 59 items and a reliability of 0,921. Based on the results of the analysis of research data shows the Pearson Correlation coefficient of 0,501 with a significance of 0,000 (0,000<0,05), so that it can be concluded that there is a significant relationship between gratification with adversity quotient ini students receiving Bidikmisi State Islamic University (UIN) Imam Bonjol Padang. These results also indicate that bidikmisi recipient students have average scores of high gratification rates and moderate dominant adversity quotient levels.
\end{abstract}

Keywords: Gratitude, Adversity Quotient, Bidikmisi Students.

\begin{abstract}
Abstrak
Penelitian ini bertujuan untuk mengetabui tingkat kebersyukuran, tingkat adversity quotient, dan bubungan rasa syukur dengan adversity quotient pada mahasiswa penerima bidikmisi UIN Imam Bonjol Padang. Penelitian ini menggunakan metode kuantitatif dengan teknik analisis data, yaitu analisis korelasi Pearson, yang diolah dengan program SPSS versi 20.0 for windows. Variabel independen dalam penelitian ini adalah kebersyukuran, dan variabel dependen adalah adversity quotient. Subjek penelitian berjumlah 229 mahasiswa yang menerima bidikmisi UIN Imam Bonjol Padang. Teknik pengumpulan data yang digunakan dalam penelitian ini adalah skala psikologis, yaitu skala rasa syukur dengan validitas 48 dari 60 item dan memiliki reliabilitas 0,934 dan skala adversity quotient dengan validitas 50 dari 59 item dan validitas 0,921. Berdasarkan hasil analisis data penelitian menunjukekan koefisien Korelasi Pearson sebesar 0,501 dengan signifikansi 0,000 (0,000 <0,05), sehingga dapat disimpulkan bahwa terdapat bubungan yang signifikan antara kebersyukuran dengan adversity quotient pada mahasiswa yang menerima bidikmisi Universitas Islam
\end{abstract}


Negeri (UIN) Imam Bonjol Padang. Hasil ini juga menunjukkan bahwa mabasiswa penerima bidikmisi memiliki skor rata-rata tingkat kebersyukuran tinggi dan tingkat kecerdasan adversiti dominan sedang.

Kata Kunci: Bersyukur, Adversity Quotient, Mahasiswa Bidikmisi.

\section{PENDAHULUAN}

Manusia adalah makhluk ciptaan Allah SW'T yang paling sempurna dibandingkan makhluk lainnya. Hal ini karena, manusia diberikan kelebihan akal untuk berpikir. Dengan kelebihannya ini, manusia bisa menjalani aktivitas kehidupannya dengan baik. Bayangkan saja, kalau seandainya manusia tidak memiliki hal tersebut. Tentunya manusia tidak dapat menjalankan fungsinya sebagai makhluk Tuhan dengan baik.

Sebagai makhluk ciptaan Allah SWT, sudah sepatutnya manusia bersyukur atas semua nikmat yang telah Allah SWT berikan. Bersyukur adalah sebuah ungkapan terima kasih kita kepada sang Pemberi nikmat. Oleh karena itu, sangat disayangkan sekali, jika seandainya ada manusia yang telah dilebihkan oleh Allah SWT nikmat kepadanya, namun tidak mampu menggunakan nikmat itu sebaik-baiknya. Bersyukur adalah sikap batin (state of mind, state of heart) yang punya efek sangat membebaskan, dan merupakan emosi positif yang sangat kuat. Berbagai penelitian ilmiah membuktikan bahwa efek bersyukur sangat baik bagi kesehatan mental dan kesehatan fisik, sangat efektif menentramkan batin dan menangkal berbagai kekecewaan serta kepahitan. ${ }^{1}$

Kebersyukuran dalam konsep psikologi positif dikenal dengan istilah gratitude. Gratitude adalah suatu perasaan menyenangkan yang khas yang akan membangkitkan perasaan dan motivasi tertentu ketika menerima kebaikan pihak lain yang menunjukkan niat yang tulus, membutuhkan pengorbanan, bernilai tinggi, bukan sekadar karena

1 Iman Setiadi Arif. 2016. Psikologi Positif: Pendekatan Saintifik Menuju Kebahagian. Jakarta: PT. Gramedia Pustaka Utama, 71 kewajiban, dan juga kebaikan itu bukan diperoleh karena usaha kita sendiri. ${ }^{2}$

Rusdi pada tahun 2016 meneliti tentang syukur dalam psikologi Islam dan konstruksi alat ukurnya. Hasil penelitian menunjukkan bahwa bersyukur merupakan variabel yang sering berhubungan dengan variabel positif lain. Bersyukur juga memiliki korelasi dengan kebahagiaan subjektif.

Mahfud pada tahun 2014 meneliti tentang the power of syukur. Hasil penelitian menunjukan bahwa semakin banyak bersyukur, semakin berlipat ganda kebahagiaan yang dirasakan. Sebagai umat muslim, Allah SWT telah memerintahkan manusia untuk bersyukur. Bahkan Allah SWT berjanji kepada orang-orang yang bersyukur akan memberi mereka balasan yang baik, sebagaimana Dia berjanji akan menghukum mereka yang durhaka. Hal ini terdapat dalam Alquran surat Ibrahim (QS. 14:7);

"Dan (ingatlah juga), tatkala Tubanmu memaklumkan; "Sesunggubnya jikea kamu bersyukur, pasti Kami akan menambah (nikmat) kepadamu, dan jikea kamu mengingkari (nikmatKu), maka sesunggubnya azab-Ku sangat pedib”.

Salah satu bentuk nikmat yang diperoleh oleh mahasiswa yang berprestasi dan tidak mampu secara ekonomi adalah adanya bantuan pendidikan mahasiswa miskin dan berprestasi dari pemerintah untuk membiayai seluruh aktivitas perkuliahan mereka yang selanjutnya akan penulis singkat dengan kata bidikmisi. Bidikmisi merupakan bantuan biaya pendidikan bagi mahasiswa tidak mampu secara ekonomi dan memiliki potensi akademik baik untuk menempuh pendidikan di

2Ibid., 73. 
perguruan tinggi pada program studi unggulan sampai lulus tepat waktu. ${ }^{3}$

Di lapangan, penulis menemukan masih terdapat keluhan mahasiswa penerima bidikmisi terhadap beasiswa tersebut, baik dari segi lamanya pencairan dana bidikmisi maupun tantangan yang diberikan seperti nilai indeks prestasi akademik dituntut untuk selalu berada di atas 3,00 di setiap semesternya, wisuda agar tepat waktu serta tidak boleh mengajukan beasiswa lain selama masih menjadi penerima aktif beasiswa bidikmisi. Dan tentunya tidak semua individu penerima beasiswa bidikmisi yang mampu menerima tantangan itu serta mampu mengontrol dan memanajemen dengan baik setiap aktivitasnya.

Santie pada tahun 2018 meneliti tentang implementasi kebijakan program bantuan beasiswa bidikmisi di Politeknik Negeri Manado. Hasil penelitian menunjukkan bahwa implementasi kebijakan program bantuan beasiswa bidikmisi dilaksanakan berdasarkan pedoman program bidikmisi dari Dikti. Dalam pelaksanaan kebijakan tersebut ditemukan faktor pendukung dan penghambat.

Setiap tantangan dan kesulitan yang muncul, diharapkan mahasiswa penerima bidikmisi mampu mengatasinya dengan baik. Karena segala kesulitan yang dihadapi, jika kita selalu memandang dengan pikiran positif dan penuh rasa syukur, akan selalu ada kemudahan dan jalan keluarnya. Sebagaimana Allah SWT berfirman dalam Alquran surat alInsyirah (QS. 94:1-8);

"Bukankah Kami telah melapangkan untukmu dadamu. Dan Kami telah menghilangkan daripadamu bebanmu. Yang memberatkan punggungmu. Dan Kami tinggikan bagimu sebutan namamu. Karena sesunggubnya sesudab kesulitan itu ada kemudahan. Sesungguhnya sesudab kesulitan itu ada kemudahan. Maka apabila kamu telah selesai (dari suatu urusan), kerjakanlah dengan

3 https://bidikmisi.belmawa.ristekdikti.go.id pada Kamis, 1 November 2018 pukul 19.08 WIB sungguh-sunggub (urusan) yang lain. Dan hanya kepada Tubanmulab hendaknya kamu berbarap".

Dari terjemahan surat al-Insyirah tersebut dapat dipahami bahwa segala kesulitan yang ditemui akan selalu ada kemudahan. Oleh karena itu, hendaknya mahasiswa penerima bidikmisi selalu memandang positif dan mampu bersyukur atas segala sesuatu yang terjadi serta mampu mencari peluang dari segala tantangan dan kesulitan yang ada sehingga dapat mengantarkannya menjadi orang yang sukses.

Berikut adalah hasil wawancara penulis dengan beberapa orang mahasiswa penerima bidikmisi UIN Imam Bonjol Padang. Penulis menanyakan terkait masalah terbesar yang ditemui oleh mahasiswa penerima beasiswa bidikmisi.

Subjek pertama yang berinisial "D" mengatakan bahwa rata-rata setiap tahunnya masalah yang ditemui adalah terkait terlambatnya pencairan dana bidikmisi. Selain dari sistem, Faktor terbesar yang menjadi penyebabnya adalah dari mahasiswa bidikmisi itu sendiri. Mahasiswa penerima bidikmisi ini sering lalai dalam memberikan laporan keuangan, sehingga berdampak pada pencairan beasiswa, sementara dana tersebut sangat mereka butuhkan untuk memenuhi segala biaya perkuliahan di kampus ini. ${ }^{4}$

Subjek kedua yang berinisial " $R$ " mengemukakan hasil yang sama pula. Bahwasanya memang masalah yang sering di temui adalah selalu terlambatnya penerimaan beasiswa bidikmisi ini setiap semesternya. Kesalahan dari kita juga karena lalai dalam memberikan laporan ke akademik pusat terkait dana yang sudah kita terima sebelumnya. Ini sangat besar sekali dampaknya pada kita. Karena dana bidikmisi ini sangat membantu saya dan hanya itu yang diharapkan untuk biaya perkuliahan sehingga saya mampu untuk mempertahankan Indeks Prestasi agar tidak berada di bawah 3,00 dan berbagai tantangan-tantangan yang lain. Jika ini 
selalu terkendala terus setiap semesternya tentu akan berdampak pula pada yang lain. ${ }^{5}$

Begitu pula dengan subjek ketiga yang berinisial "L" mengemukakan hal yang sama terkait pencairan dana bidikmisi ini. Keterlambatan pencairan dana bidikmisi itu tidak lain disebabkan oleh mahasiswa itu sendiri yang tidak melaporkan kembali dana yang telah mereka terima pada semester sebelumnya. Kelalaian yang disebabkan oleh mereka itu tidak hanya berdampak pada diri mereka sendiri tetapi juga merugikan orang banyak yaitu mahasiswa bidikmisi lainnya. Selain permasalahan diatas, ada juga terkait masalah kurang aktifnya mahasiswa bidikmisi dalam mengelola organisasi bidikmisinya. Mahasiswa bidikmisi juga dituntut untuk aktif berorganisasi. Namun fakta dilapangan, setiap mengadakan kegiatan yang berkaitan dengan bidikmisi, mereka semua menghilang, kurang kontribusinya. Semoga kedepannya bisa diperbaiki lagi. ${ }^{6}$

Sementara dikutip dari lpminkamsfeb.trunojoyo.ac.id., dinyatakan bahwa ada fenomena unik dari mahasiswa bidikmisi terkait sikap mereka sebelum dan sesudah living cost atau lazim disebut biaya hidup mereka dicairkan. Jika diperhatikan, sebelum living cost cair banyak mahasiswa bidikmisi yang mengeluh karena uang yang mereka harapkan belum didapat sedang kebutuhan dan kewajiban sudah mendesak. Lalu, setelah living cost sudah dicairkan fenomena uniknya adalah tidak ada lagi yang namanya mengeluh atau lain semacamnya. Semuanya sunyi senyap seiring dengan antrian di ATM (Anjungan Tunai Mandiri) yang padat merayap. Tidak seperti sebelum living cost cair. Bidikmisi yang merupakan salah satu beasiswa pendidikan untuk mahasiswa berprestasi, sudah selayaknya para penerimanya juga berprestasi. Berprestasi disini bukan hanya dalam hal akademik, tetapi juga dalam hal sikap dan perilaku. Jadi, sudah

\footnotetext{
${ }^{5}$ R, Wawancara, Padang, 01/11/2018

${ }^{6}$ L, Wawancara, Padang, 01/11/2018
}

seharusnya sebagai mahasiswa penerima bidikmisi perilaku lalai ini dikurangi. Selain itu, dalam memenuhi kewajiban-kewajibannya sebagai penerima bidikmisi, hendaknya mereka mampu mencari peluang dari segala kesulitan sehingga bisa bertahan dan sukses sampai akhir. ${ }^{7}$

Berdasarkan hasil penelitian yang dilakukan oleh Dhea (2016:580) yang menyatakan bahwa tingkat stres akademik pada mahasiswa bidikmisi yaitu tinggi $15 \%$, sedang $65 \%$ dan rendah 19\%. Hal ini berarti dalam memenuhi tuntutan-tuntutan akademiknya, mahasiswa penerima beasiswa bidikmisi juga tergolong memiliki tingkat stress berada pada kategori sedang.

Sementara, pada penelitian yang dilakukan oleh Musabiq pada tahun 2018 tentang Stres, motivasi berprestasi, bersyukur, dan perceived social support: Analisis optimisme pada mahasiswa penerima bidikmisi. Hasil penelitiannya menunjukan bahwa semakin tinggi tingkat optimisme mahasiswa, maka semakin tinggi pula rasa syukur, motivasi berprestasi, dan dukungan sosial yang dirasakan, serta semakin rendah tingkat stresnya. ${ }^{8}$ Hal ini berarti ketika mahasiswa bidikmisi mampu bersikap optimistik terhadap segala tantangan yang diberikan serta betul-betul bersyukur atas semua nikmat yang ada, maka mereka akan mampu menjalani semua tantangan dengan sebaik-baiknya. Bahkan, mampu mengantarkan mereka untuk memperoleh prestasi yang lebih baik. Berikut adalah hasil wawancara lanjutan yang dilakukan penulis kepada beberapa orang mahasiswa penerima beasiswa bidikmisi Universitas Islam Negeri (UIN) Imam Bonjol Padang. Penulis menanyakan terkait

${ }^{7}$ https://lpminkams-feb.trunojoyo.ac.id diakses pada Sabtu, 3 November 2018 pukul 14.02 WIB.

${ }^{8}$ Lu'luMusabiq, Adila Sari, dan Hervi.2018. Stres, Motivasi Berprestasi, Bersyukur, dan Perceived Social Support: Analisis Optimisme padaMahasiswa Penerima Beasiswa Bidikmisi. Jurnal Vol. 4 No. 1.Depok : Universitas Indonesia., 54. 
tantangan dan tanggapannya sebagai mahasiswa penerima beasiswa bidikmisi.

Subjek keempat yang berinisial " $\mathrm{V}$ " mengatakan bahwa sebagai mahasiswa penerima bidikmisi tentunya kita diberikan tantangantantangan. Salah satunya terkait Indeks Prestasi harus mencukupi sebanyak 3,00. Jika tidak tercapai maka akan diberikan peringatan. Dia sangat bersyukur sekali karena bisa menerima bidikmisi ini. Selain kuliah, dia juga aktif berorganisasi. Terkait nilai indeks prestasinya semester satu 4,00 dan semester selanjutnya juga 4,00. ${ }^{9}$

Berikutnya adalah wawancara kelima terkait kebersyukuran. Subjek yang memiliki inisial "Y" ini mengatakan bahwa ia sangat bersyukur sekali dengan adanya bidikmisi tersebut. Karena ada kelebihan dan keistimewaan dibandingkan mahasiswa lain. Jika mahasiswa lain masih ditanggung biaya perkuliahannya dari orangtua masing-masing sedangkan beliau tidak. Jadi sudah sepatutnya kita harus berterima kasih. Tapi karena perkembangan zaman dan tidak bisa memanajemen diri dan waktu dengan baik selama perkuliahan, nilai indeks prestasi beliau menurun dibandingkan semester selanjutnya. ${ }^{10}$

Untuk menghadapi tantangan dan tekanan dibutuhkan adanya kekuatan untuk menyelesaikannya. Kemampuan untuk menghadapi tantangan dan tekanan tersebut dinamakan dengan adversity quotient. Adversity quotient adalah kemampuan individu untuk bertahan menghadapi kesulitan dan kemampuan untuk mengatasinya. Stoltz -dalam Sapuri- menjelaskan bahwa kebanyakan orang berhenti berusaha sebelum tenaga dan batas kemampuan mereka benar-benar teruji. ${ }^{11}$ Ungkapan Stoltz tersebut mengindikasikan bahwa ketangguhan manusia ada pada siapapun yang

\footnotetext{
${ }^{9} \mathrm{~V}$, Wawancara, Padang 22/09/2018

${ }^{10}$ Y, Wawancara, Padang 23/09/2018

11 RafySapuri. 2017. Psikologi Islam: Tuntutan Jiwa Manusia Modern. Jakarta: Rajawali Pers., 188
}

mampu mengekspresikan segala potensi yang ada pada dirinya. ${ }^{12}$

Menurut Stoltz seperti dikutip oleh Octavia, mahasiswa yang memiliki tingkat adversity quotient yang tinggi ditandai dengan adanya kemampuan dan ketahanan untuk menghadapi kesulitan, pantang menyerah, dan memiliki tanggung jawab dalam menyelesaikan segala persoalan dalam hidup. Mahasiswa yang memiliki ketahanan dan semangat pantang menyerah dapat memaksimalkan waktunya dengan baik untuk memenuhi kewajiban-kewajiban sebagai mahasiswa penerima bidikmisi. Mahasiswa penerima bidikmisi dihadapkan dengan berbagai tuntutan dan tanggung jawab, baik dari kampus maupun dari pemerintah sebagai pihak yang memberikan beasiswa.

Mahasiswa penerima bidikmisi diharuskan untuk menyelesaikan kuliah tepat waktu dengan Indeks Prestasi di atas 3. Selain itu, mahasiswa dituntut untuk aktif berorganisasi. Apabila mahasiswa penerima bidikmisi tidak memenuhi segala persyaratan tersebut maka mahasiswa yang bersangkutan akan mendapatkan surat peringatan dan pemberian bantuan beasiswa terancam tidak dilanjutkan. Oleh karena itu, di tengah keterbatasannya, mahasiswa penerima bidikmisi dituntut untuk optimal dalam menjalankan tanggung jawabnya khususnya dalam perkuliahannya. ${ }^{13}$

Meskipun terdapat banyak keuntungan yang diterima oleh mahasiswa dari beasiswa bidikmisi, masalah individu dalam memenuhi tuntutannya tidak selalu mulus. Oleh karena itu, diharapkan agar mahasiswa penerima bidikmisi ini selalu bersyukur terhadap segala tantangan hidup yang ada. Bersyukur sendiri juga diartikan sebagai reaksi emosi positif sebagai respon terhadap penerimaan

12 Paul GStoltz. 2005. Adversity Quotient: Faktor Paling Penting dalam Meraih Sukses. Jakarta: PT. Gramedia., 34.

13 Efi Octavia. 2013. Hubungan Antara Adversity Quotient dan Work-Study Conflict pada Mahasiswa yang Bekerja. JurnalV ol.1No.1. Yogyakarta: UniversitasIslam Indonesia., 47. 
karunia atau keuntungan dari seseorang. ${ }^{14}$ Segala tantangan yang ada akan membuat seseorang menjadi pribadi yang tangguh serta mempunyai daya juang yang tinggi. Dengan adanya rasa syukur kepada Allah SWT akan tercipta suatu pandangan yang positif terhadap segala permasalahan yang terjadi. Jika seseorang bersyukur, maka secara otomatis pandangannya akan menjadi positif. Penilaian positif ini sangat berguna bagi mahasiswa dalam mengevaluasi pengalaman-pengalamannya dengan segala tuntutan dan tanggung jawab yang dihadapinya, sehingga individu mampu mengatasi segala tantangan yang ada. ${ }^{15}$

Universitas Islam Negeri (UIN) Imam Bonjol Padang merupakan salah satu perguruan tinggi agama Islam yang berada di Sumatera Barat. Disini terdapat enam fakultas yang terdiri dari Fakultas Tarbiyah dan Keguruan, Fakultas Dakwah dan Ilmu Komunikasi, Fakultas Adab dan Humaniora, Fakultas Syari'ah, Fakultas Ushuluddin dan Studi Agama, serta Fakultas Ekonomi dan Bisnis Islam. Di dalam kampus ini terdapat berbagai civitas akademika termasuk mahasiswa. Mahasiswa adalah peserta didik yang terdaftar dalam salah satu program studi yang ada di UIN Imam Bonjol Padang. ${ }^{16}$

Dilansir dari Data Akademik Rektorat UIN Imam Bonjol Padang, mahasiswa aktif penerima Bidikmisi tahun akademik 2018/2019 sebanyak 539 orang. Mereka tersebar di berbagai fakultas dan angkatan. Mulai dari angkatan 2015, 2016, 2017, hingga 2018. Sebagai mahasiswa penerima bidikmisi yang menuntut ilmu di kampus ini tentunya mereka memahami akan hakikat kebersyukuran atas sebuah nikmat yang mereka peroleh. Hal ini dikarenakan

${ }^{14}$ Lu'luMusabiq dkk. Stres, MotivasiBerprestasi..., 24.

15 NurYatimah,. 2016. Hubungan Rasa Syukur dengan Regulasi Diri pada Mahasiswa Berprestasi Penerima Beasiswa Bidikmisi IAIN Tulungagung. Tulungagung: Skripsi Tidak diterbitkan, IAINTulungagung, 6

16 Tim Penyusun. 2015. Pedoman Akademik,Pedoman Kemahasiswaan, dan Pedoman Penulisan Karya Ilmiah. Padang: IAIN IB Padang., 40. mereka memperoleh mata kuliah keagamaan lebih dalam dibandingkan kampus umum lainnya. Tentunya dengan pemahaman agama yang mendalam, mereka mampu untuk menghadapi semua tantangan yang diberikan sebagai mahasiswa bidikmisi. Karena mereka menyadari tidak semua mahasiswa bisa memperoleh beasiswa bidikmisi seperti yang mereka dapatkan.

Namun berdasarkan wawancara yang peneliti lakukan lebih lanjut dengan Kasubag Kemahasiswaan UIN Imam Bonjol Padang, dalam hal ini berinisial $\mathrm{H}$ usia 46 tahun, menyatakan bahwa sebagai mahasiswa penerima bidikmisi memang mereka diberikan tantangan-tantangan seperti tidak boleh menikah, IP harus diatas 3, dan lain-lain berupa perjanjian yang tertuang dalam fakta integritas yang ditandatangani mereka sebelum menerima bidikmisi. Setiap tahunnya memang ada diantara mereka penerima bidikmisi ini yang diberhentikan baik berupa kasus IP dibawah 3, menikah, wisuda tidak tepat waktu yang kalau dipersentasekan dibawah 50\%. Bahkan ada juga diantara mereka yang memiliki nilai E. Ada lagi hal yang sangat disayangkan dari mahasiswa penerima bidikmisi ini yaitu berkaitan dengan kelalaian mereka dalam memberikan laporan terkait keuangan setiap semesternya bahkan ada diantara mereka sudah satu tahun tidak memberikan laporan keuangan tersebut. Hal ini tentu sangat berdampak buruk sekali bagi lembaga maupun bagi mereka sendiri karena akan memperlambat proses pencairan dana mereka untuk semester selanjutnya. Beliau berharap mahasiswa penerima bidikmisi ini sadar betul akan hak dan kewajiban mereka, betulbetul belajar, bersyukur atas nikmat yang ada, bahkan kalau bisa mereka dapat melanjutkan S2 sehingga masa depan mereka dapat menjadi lebih bagus lagi. ${ }^{17}$

Hal inilah yang menjadikan peneliti tertarik untuk meneliti konsep kebersyukuran ini.

${ }^{17}$ H, Wawancara, Padang, 27/11/2018 
Bersyukur merupakan variabel yang sering berhubungan dengan variabel positif lain (Rusdi, 2016:39). Karena syukur bukanlah kata benda mati. Syukur juga bukan kata sifat saja. Tapi, syukur merupakan kata kerja yang perlu bukti tindakan nyata hingga akhir hayat kita. Secara lisan, praktik syukur bisa dibuktikan dengan mengucapkan katakata yang baik sekaligus pujian hanya untuk Allah. Dalam tindakan, syukur ditandai dengan upaya sungguh-sungguh untuk memanfaatkan apa saja yang bisa kita lakukan untuk kemanfaatan dan kemaslahatan semua.

Dalam buku Dabsyatnya Syukur, Syafii AlBantanie (Mahfud, 2014:393) menerangkan secara lugas, betapa syukur memberikan pengaruh besar bagi pelakunya. Tidak hanya dimudahkan dari segala kesulitan, tapi juga mendatangkan dan menambah rezeki. Intinya, ia mengungkap bahwa syukur memiliki hikmah yang besar. Syukur merupakan energi yang dahsyat untuk menggapai kesuksesan dan kebahagiaan hidup di dunia dan di akhirat. $^{18}$

Berdasarkan uraian permasalahan diatas, maka peneliti akan meneliti tentang hubungan kebersyukuran dengan adversity quotient pada mahasiswa penerima bantuan pendidikan mahasiswa miskin berprestasi (Bidikmisi) UIN Imam Bonjol Padang.

\section{METODE PENELITIAN}

Jenis penelitian yang digunakan dalam penelitian ini adalah penelitian kuantitatif dengan metode korelasi. Penelitian dilaksanakan di Universitas Islam Negeri (UIN) Imam Bonjol Padang pada bulan Juni tahun 2019.Variabel bebas dalam penelitian ini adalah kebersyukuran dan variabel terikatnya adalah adversity quotient.

Populasi dalam penelitian ini adalah mahasiswa penerima bidikmisi UIN Imam Bonjol

18 Choirul Mahfud. 2014. The Power Of Syukur.Jurnal Vol.9 No.2. Surabaya: Lembaga Kajian Agama dan Sosial. 81
Padang angkatan 2015-2018 yang keseluruhan berjumlah 539 mahasiswa. Pengambilan sampel pada penelitian ini menggunakan teknik probability sampling. Sampel pada penelitian ini berjumlah 229 orang mahasiswa penerima bidikmisi UIN Imam Bonjol Padang.Instrumen yang digunakan dalam penelitian ini adalah skala kebersyukuran dan skala adversity quotient.

Pengujian tingat Validitas menggunakan validitas isi dengan menggunakan metode expert judgement yaitu dosen pembimbing pada skala adversity quotient dan dosen ahli skala kebersyukuran. Uji reliabilitas menggunakan rumus Alpha Cronbach yang diperoleh koefisien 0,934 untuk skala kebersyukuran dan 0,921 untuk skala adversity quotient.

Teknik analisis data yang digunakan dalam penelitian ini yaitu dengan uji hipotesis pearson correlation. Adapun persyaratan yang dilakukan terlebih dahulu yaitu:

1. Uji Normalitas, digunakan untuk mengetahuiapakahdata berdistribusi normal atau tidak. Pada penelitian ini akan digunakan metode One Sample Kolmogorov-Smirnov. Data berdistribusi normal jika signifikansi lebih besar dari 0,05 (Priyatno, 2011:39).

2. Uji Linearitas, digunakan untuk mengetahui linieritas data, apakah dua variabel mempunyai hubungan yang linier atau tidak. Uji ini digunakan sebagai prasyarat dalam analisis korelasi person atau regresi linier. Data linier bila Test for Linerity pada taraf signifikansi kurang dari $0,05 .^{19}$

\section{TEMUAN}

Hasil skor kebersyukuran dikategorisasikan menjadi tiga kategori yaitu tinggi, sedang, dan rendah. Adapun hasilnya sebagai berikut:

19 Duwi Priyatno. 2011. Buku Saku Analisis Statistik Data SPSS. Yogyakarta: MediaKom, 79 
Tabel 1

Kategorisasi Skala Kebersyukuran Mahasiswa Bidikmisi

\begin{tabular}{|c|l|l|l|l|}
\hline No & Skor & Jumlah & Kategorisasi & Persentase \\
\hline 1 & $>144$ & 157 & Tinggi & $68,6 \%$ \\
\hline 2 & $96-143$ & 72 & Sedang & $31,4 \%$ \\
\hline 3 & $<96$ & - & Rendah & - \\
\hline
\end{tabular}

Berdasarkan tabel 1 di atas, bahwa dari 229 subjek yang diteliti 157 orang atau 68,6\% memiliki tingkat kebersyukuranyang tinggi, sebanyak 72 orang atau $31,4 \%$ memiliki tingkat kebersyukuransedang, dan tidak ada satupun dari subjek penelitian yang mendapatkan nilai terendah atau $0 \%$. Artinya tidak ada satupun dari mahasiswa penerima bidikmisi yang tidak bersyukur atas beasiswa yang mereka peroleh. Dari besarnya persentase kebersyukuranpada tabel tersebut, menunjukkan bahwa mahasiswa penerima bidikmisi UIN Imam Bonjol Padang lebih dominan memiliki tingkat kebersyukuranyang dikategorikan tinggi.

Hasil skor adversity quotient dikategorisasikan menjadi tiga kategori yaitu tinggi, sedang, dan rendah. Adapun hasilnya sebagai berikut:

Tabel 2

Kategorisasi Skala Adversity Quotient Mahasiswa Bidikmisi

\begin{tabular}{|c|c|c|c|c|}
\hline No & Skor & Jumlah & Kategorisasi & Persentase \\
\hline 1 & $\geq 175$ & 13 & Tinggi & $5,7 \%$ \\
\hline 2 & $125-174$ & 212 & Sedang & $92,6 \%$ \\
\hline 3 & $<125$ & 4 & Rendah & $1,7 \%$ \\
\hline
\end{tabular}

Berdasarkan tabel 2 di atas, bahwa dari 229 subjek yang diteliti 13 orang atau 5,7\% memiliki tingkat adversity quotient yang tinggi, sebanyak 212 orang atau 92,6\% memiliki tingkat adversity quotient sedang, dan 4 orang atau 1,7\% memiliki tingkat adversity quotient rendah. Dari besarnya persentase adversity quotient pada tabel tersebut, menunjukkan bahwa mahasiswa penerima bidikmisi UIN Imam Bonjol Padang lebih dominan memiliki tingkat kemampuan adversity quotient yang dikategorikan sedang.

Tabel 3

Uji Normalitas

\begin{tabular}{|l|l|l|l|}
\hline \multicolumn{2}{|l|}{} & $\mathrm{X}$ & $\mathrm{Y}$ \\
\hline $\mathrm{N}$ & 229 & 229 & \\
\hline
\end{tabular}

\begin{tabular}{|l|l|l|l|}
\hline \multirow{2}{*}{$\begin{array}{l}\text { Normal } \\
\text { Parametersa }\end{array}$} & Mean & 151.54 & 153.86 \\
\cline { 2 - 4 } & $\begin{array}{l}\text { Std. } \\
\text { Deviation }\end{array}$ & 15.236 & 13.499 \\
\hline \multirow{2}{*}{$\begin{array}{l}\text { Most Extreme } \\
\text { Differences }\end{array}$} & Absolute & .042 & .079 \\
\cline { 2 - 4 } & Positive & .042 & .070 \\
\cline { 2 - 4 } & Negative & -.038 & -.079 \\
\hline $\begin{array}{l}\text { Kolmogorov- } \\
\text { Smirnov Z }\end{array}$ & .631 & 1.200 & \\
\hline $\begin{array}{l}\text { Asymp. Sig. (2- } \\
\text { tailed) }\end{array}$ & .821 & .112 & \\
\hline \multicolumn{3}{|l|}{ Test distribution is Normal. } \\
\hline
\end{tabular}

Hasil uji normalitas pada tabel 3 menunjukkan bahwa nilai signifikansi (Asymptotic Significance 2-tailed) untuk kebersyukuran 0,821 dan adversity quotient adalah 0,112. Signifikansi untuk variabel kebersyukuran dan adversity quotient lebih besar dari 0,05 maka berdistribusi normal. Jadi dapat disimpulkan bahwa pada skala kebersyukuran dan adversity quotient berdistribusi normal.

Hasil uji linieritas menunjukkan bahwa pada output Anova Table nilai signifikansi pada linieritas sebesar 0,000, karena signifikansi kecil dari 0,05 $(0,000<0,05)$ maka dapat disimpulkan bahwa antara variabel kebersyukuran dan adversity quotient terdapat hubungan yang linier, maka asumsi linieritas terpenuhi.

Tabel 5

Uji Hipotesis

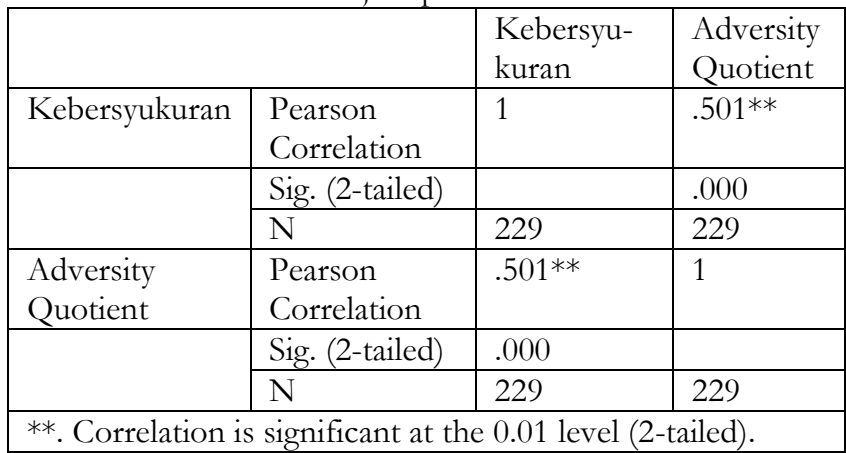

Hasil uji hipotesis pada Pearson Correlation menunjukkan bahwa nilai koefisien Pearson Correlation kebersyukurandan adversity quotient sebesar 0,501. Nilai signifikansi dari kebersyukuran dan adversity quotient adalah 0,000 $(0,000<0,05)$ yang berarti pada taraf signifikansi antara dua variabel, menunjukkan adanya hubungan antara 
kebersyukurandenganadversity quotient pada mahasiswapenerima bidikmisi UIN Imam Bonjol Padang.

\section{PEMBAHASAN}

Pada sub-bab ini pembahasannya adalah tentanghasil dari kegiatan penelitian yang telah dilakukan. Berdasarkan kategorisasi yang dilakukan menunjukkan bahwa dari 229 subjek yang diteliti 157 orang atau 68,6\% memiliki tingkat kebersyukuranyang tinggi, sebanyak 72 orang atau $31,4 \%$ memiliki tingkat kebersyukuransedang, dan tidak ada satupun dari subjek penelitian yang mendapatkan nilai terendah atau $0 \%$. Artinya tidak ada satupun dari mahasiswa penerima bidikmisi yang tidak bersyukur atas beasiswa yang mereka peroleh.

Dari besarnya persentase kebersyukuranpada tabel 14 tersebut, menunjukkan bahwa mahasiswa penerima bidikmisi UIN Imam Bonjol Padang lebih dominan memiliki tingkat kebersyukuranyang dikategorikan tinggi. Sedangkan untuk kategorisasi adversity quotient menunjukkan bahwa dari 229 subjek yang diteliti 13 orang atau 5,7\% memiliki tingkat adversity quotient yang tinggi, sebanyak 212 orang atau 92,6\% memiliki tingkat adversity quotient sedang, dan 4 orang atau 1,7\% memiliki tingkat adversity quotient rendah. Dari besarnya persentase adversity quotient pada tabel tersebut, menunjukkan bahwa mahasiswa penerima bidikmisi UIN Imam Bonjol Padang lebih dominan memiliki tingkat kemampuan adversity quotient yang dikategorikan sedang.

Sementara, untuk hasil uji hipotesis menunjukkan adanya hubungan antara kebersyukurandenganadversity quotient pada mahasiswa penerima bidikmisi UIN Imam Bonjol Padang.

Berdasarkan penelitian yang pernah dilakukan sebelumnya oleh Gumilar yang meneliti tentang kebersyukuran dan kebermaknaan hidup pada mahasiswa. ${ }^{20}$ Hasil penelitian menunjukan bahwa ada hubungan yang signifikan antara kebersyukuran dan kebermaknaan hidup pada mahasiswa dengan $r$ $=0,490$ dan signifikansi $\mathrm{p}$ value sebesar 0,000 atau $\mathrm{p}$ $<0,05$.

Musabiq pada 2018 meneliti tentang Stres, Motivasi Berprestasi, Bersyukur, dan Perceived Social Support: Analisis Optimisme pada Mahasiswa Penerima Beasiswa Bidikmisi. ${ }^{21}$ Hasil penelitian menunjukan bahwa ada hubungan yang signifikan antara optimisme dan stres $(\mathrm{r}=-0.158 ; \mathrm{p}<0.05)$; optimisme dan motivasi berprestasi ( $\mathrm{r}=0.15$; $\mathrm{p}<0.05)$; optimisme dan rasa syukur $(\mathrm{r}=0.267$; $\mathrm{p}<0.05)$; dan optimisme dan dukungan sosial yang dirasakan $(\mathrm{r}=0.351 ; \mathrm{p}<0.05)$.

Yatimah pada tahun 2016 meneliti tentang hubungan rasa syukur dengan regulasi diri pada mahasiswa berprestasi penerima beasiswa bidikmisi IAIN Tulungagung. ${ }^{22}$ Hasil penelitian menunjukan bahwa terdapat hubungan yang signifikan antara rasa syukur dengan regulasi diri pada mahasiswa berprestasi penerima beasiswa bidikmisi IAIN Tulungagung. Hal tersebut ditunjukkan dari hasil perhitungan statistik dengan menggunakan metode Product Moment Pearson menunjukkan bahwa nilai $\mathrm{r}$ hubungan rasa syukur dengan regulasi diri adalah 0,000. Artinya nilai sig. $<0,05(0,000<0,05)$ dan dengan demikian korelasi antara kedua variabel adalah signifikan.

Utami pada tahun 2016 meneliti tentang perbedaan tingkat kecerdasan adversity mahasiswa bidikmisi dan non bidikmisi Fakultas Ilmu Pendidikan Universitas Negeri Yogyakarta. ${ }^{23}$ Hasil penelitian menunjukan bahwa terdapat perbedaan

${ }^{20}$ Gumilar \& Qurotul Uyun. 2009. Kebersyukuran dan Kebermaknaan Hidup pada Mahasiswa. Jurnal Psikologika Volum 13 No 1. Yogyakarta: Universitas Islam Indonesia.

${ }^{21}$ Lu'luMusabiq dkk. Stres, MotivasiBerprestasi..., 24.

${ }^{22}$ NurYatimah, Hubungan Rasa Syukur ..., 6

23 Rizki MeitaUtami. 2016. Perbedaan Tingkat Kecerdasan Adversity Mahasiswa Bidikmisi dan Non-Bidikmisi Fakultas Ilmu Pendidikan Universitas Negeri Yogyakarta. Jurnal. Yogyakarta: Universitas Negeri Yogyakarta. 
yang signifikan tingkat kecerdasan adversity mahasiswa bidikmisi dan non bidikmisi dengan sig $=0,000 ; \mathrm{p}<0,05$, nilai $\mathrm{t}=7,739$. Rata-rata skor tingkat kecerdasan adversity mahasiswa bidikmisi yaitu 113,76 dan mahasiswa non bidikmisi yaitu 105,65. Hasil ini menunjukkan bahwa mahasiswa bidikmisi memiliki skor rata-rata tingkat kecerdasan adversity lebih tinggi daripada mahasiswa non bidikmisi, meskipun rata-rata keduanya berada pada kategori tingkat kecerdasan adversity sedang.

Sementara, Mahfud pada tahun 2014 yang meneliti tentang the power of syukur. Hasil penelitian menunjukan bahwa semakin banyak bersyukur, semakin berlipat ganda kebahagiaan yang dirasakan. ${ }^{24}$ Syukur termasuk bagian dari ajaran Islam tentang "terima kasih" yang penting dan sangat diperhatikan di mata Allah SW'T sekaligus juga bagi manusia. Seseorang yang betul-betul bersyukur terhadap semua nikmat yang telah ia peroleh, apapun tantangan yang diberikan dalam rangka mengelola nikmat yang ada niscaya ia akan mampu melakukannya. Karena ia memahami bahwa tidak semua orang bisa mendapatkan nikmat seperti yang ia dapatkan. Ditambah lagi apabila ia merupakan seorang yang paham akan ilmu agama tentu dia akan mampu memanfaatkannya dalam rangka wujud ketaatannya kepada Sang Pemberi Nikmat. Kemampuan seseorang dalam menghadapi berbagai tantangan dan kesulitan serta mampu mengatasinya disebut dengan adversity quotient. Dengan demikian dapat disimpulkan bahwa ada hubungan yang signifikan antara variabel kebersyukuran ini dengan adversity quotient.

Apabila kita pandai dalam memaknai seluruh kenikmatan yang diterima dengan rasa syukur, tentu kita yakin dengan kebaikan-kebaikan yang segera dirasakan pada setiap episode kehidupan. Karena dengan senantiasa bersyukur, niscaya kelapangan hidup akan kita temui dan

${ }^{24}$ Choirul Mahfud. 2014. The Power Of Syukur...., 81. kesempitan yang dirasakan segera beranjak pergi. Namun, apabila kita lalai untuk mensyukurinya, kesempitan hidup akan menjadi sebuah keniscayaan yang senantiasa kita hadapi.

Begitu pula di saat kesulitan menghimpit, saatnya kita kembali merenungi nikmat-nikmat Allah SWT yang selama ini telah dikaruniakan-Nya. Dengan mensyukuri apa pun nikmat yang telah diterima, Insya Allah akan ditemukan begitu banyak keindahan lain sehingga kesulitan yang dihadapi terasa mudah untuk dilalui. ${ }^{25}$

Hal ini juga telah Allah SWT katakan di dalam Alquran surat Ibrahim (QS. 14:7);

"Dan (ingatlah juga), tatkala Tuhanmu memaklumkan; "Sesunggubnya jika kamu bersyukur, pasti Kami akan menambah (nikmat) kepadamu, dan jika kamu mengingkari (nikmatKu), maka sesunggubnya azab-Ku sangat pedib”.

Dari penjelasan ayat di atas dapat kita pahami bahwa, semakin kita bersyukur atas suatu nikmat yang telah kita peroleh, maka akan semakin Allah SWT tambah nikmat lain kepada kita. Salah satunya nikmat kemudahan dalam mengatasi segala persoalan kehidupan.

Sebagaimana Allah SWT juga berfirman dalam Alquran surat al-insyirah (QS. 94:1-8);

"Bukankah Kami telah melapangkan untukmu dadamu. Dan Kami telah menghilangkan daripadamu bebanmu. Yang memberatkan punggungmu. Dan Kami tinggikan bagimu sebutan namamu. Karena sesunggubnya sesudah kesulitan itu ada kemudahan. Sesunggubnya sesudab kesulitan itu ada kemudahan. Maka apabila kamu telah selesai (dari suatu urusan), kerjakanlah dengan sungguh-sunggub (urusan) yang lain. Dan hanya kepada Tuhanmulab hendaknya kamu berharap”.

Dari terjemahan surat al-Insyirah tersebut dapat dipahami bahwa segala kesulitan yang ditemui akan selalu ada kemudahan. Oleh karena itu, hendaknya mahasiswa penerima bidikmisi selalu memandang positif dan mampu bersyukur atas

25 Mohamad Nuruddin Ma'mun. 2010. Kekuatan dan Nikmatnya Bersyukur. Jakarta: Belanoor. 3. 
segala sesuatu yang terjadi serta mampu mencari peluang dari segala tantangan dan kesulitan yang ada sehingga dapat mengantarkannya menjadi orang yang sukses.

Hasil penelitian dari data, menunjukkan bahwa ada hubungan yang signifikan antara kebersyukuran dan adversity quotient pada mahasiswa penerima bantuan pendidikan mahasiswa miskin berprestasi (bidikmisi) Universitas Islam Negeri (UIN) Imam Bonjol Padang. Hal ini terbukti dari koefisien correlation pearson sebesar 0,501 dengan signifikansi $0,000(0,000,<0,05)$, sehingga dapat disimpulkan bahwa terdapat hubungan yang signifikan antara kebersyukuran dan adversity quotient pada mahasiswa penerima bantuan pendidikan mahasiswa miskin berprestasi (bidikmisi) Universitas Islam Negeri (UIN) Imam Bonjol Padang.

\section{PENUTUP}

Berdasarkan hasil analisis data dan pembahasan, maka kesimpulan yang dapat diambil dari penelitian ini adalah terdapat hubungan antara kebersyukuran dengan adversity quotient pada mahasiswa penerima bantuan pendidikan mahasiswa miskin berprestasi (bidikmisi) UIN Imam Bonjol Padang. Mahasiswa penerima bidikmisi memiliki rata-rata skor tingkat kebersyukuran tinggi dan skor tingkat adversity quotient dominan sedang.

Diharapkan kepada mahasiswa penerima Bidikmisi agar dapat meningkatkan dan mempertahankan perilaku bersyukur. Karena semakin bersyukur atas beasiswa yang telah diperoleh, maka akan semakin mudah dalam menghadapi segala persoalan kehidupan, sehingga segala tantangan yang dihadapi dapat terselesaikan dengan baik.

Diharapkan juga bagi Pemerintah agar terus melanjutkan program bidikmisi. Karena berkat adanya program bidikmisi, banyak anak-anak bangsa yang kurang dari sisi ekonomi dapat melanjutkan pendidikan ke perguruan tinggi.

Dengan adanya keterbatasan dalam penelitian ini, kepada peneliti selanjutnya yang tertarik dengan tema yang sama disarankan untuk melakukan penulusuran sumber dan literatur yang lebih banyak guna memperkaya dan menambah penguatan terhadap teori-teori yang mendukung. Melakukan pengaitan dengan memperhatikan variabel lain yang mungkin berpengaruh terhadap adversity quotient, kemudian mengambil wilayah penelitian yang lebih luas, melakukan penelitian terhadap sampel yang lebih banyak, kemudian menggunakan rancangan penelitian yang lebih kompleks yaitu menggunakan pendekatan secara mixed method maupun eksperimen sehingga mendapatkan hasil yang lebih optimal, serta melakukan perbaikan terhadap instrumen penelitian yaitu dengan memperhatikan isian butir skala dan melakukan penambahan butir item pada skala kebersyukuran dan adversity quotient.

\section{DAFTAR KEPUSTAKAAN}

Arif,Iman Setiadi. 2016. Psikologi Positif: Pendekatan Saintifik Menuju Kebahagian. Jakarta: PT. Gramedia Pustaka Utama.

Gumilar \& Qurotul Uyun. 2009. Kebersyukuran dan Kebermaknaan Hidup pada Mahasiswa. Jurnal Psikologika Volum 13 No 1. Yogyakarta: Universitas Islam Indonesia.

Mahfud, Choirul. 2014. The Power of Syukur.Jurnal Vol.9 No.2. Surabaya: Lembaga Kajian Agama dan Sosial.

Ma'mun, Mohamad Nuruddin. 2010. Kekuatan dan Nikmatnya Bersyukur. Jakarta: Belanoor.

Musabiq,Lu'lu, Adila Sari, dan Hervi.2018. Stres, Motivasi Berprestasi, Bersyukur, dan Perceived Social Support: Analisis Optimisme padaMahasiswa Penerima Beasiswa Bidikmisi. Jurnal Vol. 4 No. 1.Depok : Universitas Indonesia.

Octavia, Efi. 2013. Hubungan Antara Adversity Quotient dan Work-Study Conflict pada 
Mahasiswa yang Bekerja. Jurnal Vol.1 No.1. Yogyakarta: UniversitasIslam Indonesia.

Priyatno, Duwi. 2011. Buku Saku Analisis Statistik Data SPSS. Yogyakarta: MediaKom.

Santie, Johannes Kristoffel. 2018. Implementasi Kebijakan Program Bantuan Beasiswa Bidikmisi di Politeknik Negeri Manado. Manado: Politeknik Negeri Manado

Sapuri,Rafy. 2017. Psikologi Islam: Tuntutan Jiwa Manusia Modern. Jakarta: Rajawali Pers.

Stoltz, Paul G. 2005. Adversity Quotient: Faktor Paling Penting dalam Meraih Sukses. Jakarta: PT. Gramedia.

Tim Penyusun. 2015. Pedoman Akademik, Pedoman Kemahasiswaan, dan Pedoman Penulisan Karya Ilmiah. Padang: IAIN IB Padang.

Utami, Rizki Meita. 2016. Perbedaan Tingkat Kecerdasan Adversity Mahasiswa

Bidikmisi dan Non-Bidikmisi Fakultas Ilmu Pendidikan Universitas Negeri Yogyakarta. Jurnal. Yogyakarta: Universitas Negeri Yogyakarta.

Yatimah,Nur. 2016. Hubungan Rasa Syukur dengan Regulasi Diri pada Mahasiswa Berprestasi Penerima Beasiswa Bidikmisi LAIN Tulungagung. Tulungagung: Skripsi Tidak diterbitkan, IAINTulungagung.

https://bidikmisi.belmawa.ristekdikti.go.id diakses pada Kamis, 1 November 2018 pukul 19.08 WIB

https://lpminkams-feb.trunojoyo.ac.id diakses pada Sabtu, 3 November 2018 pukul 14.02 WIB. 